Original research article

\title{
Nurses and midwives in Slovakia - important trends and ageing of the nursing workforce
}

\author{
Silvia Megyesiová \\ University of Economics in Bratislava, Faculty of Business Economy with seat in Košice, Košice, Slovak Republic
}

\begin{abstract}
Introduction: Nurses and midwives play an important role in society and are essential for each human being. In Slovakia, nurses and midwives constitute the most significant group of employees in the health care institutions.

Methods: The data regarding the number of nurses and midwives in Slovakia were collected from 2000 to 2019 . Chain indexes and/or fixed-base indexes were used to follow the changes of the nursing workforce. The ageing of nurses and midwives was determined by mean age and age structure. Correlation analysis was selected to detect the association between the living standard and number of nursing workforce per 1,000 people in the EU.

Results: The total number of nurses and midwives in Slovakia decreased from 40,380 in 2000 to 33,041 in 2019. This decline of the nursing workforce by $18.2 \%$ is a negative signal for the Slovak health care system. Ageing of the nursing workforce is the second negative sign for health system in Slovakia. The age structure of nurses and midwives has changed significantly. The number of nurses over 60 years of age was more than 13 times higher in 2019 compared to the year 2000. The changed age structure resulted in an increase of the mean age of the nursing workforce. The mean age of nurses increased from 37.2 in 2000 to 46.9 in 2019. In the case of midwives, the average age increased from 40.9 to 47.4 .

Conclusions: The decrease of the nursing workforce along with the ageing of nurses and midwives could result in a nursing shortage in Slovakia. To stop this trend towards a nursing shortage, the Slovak government should more actively solve the problem of renumeration, create a better work environment for the nursing workforce, and promote the importance and status of nurses and midwives in Slovakia.
\end{abstract}

Keywords: Ageing; European Union; Midwives; Nurses; Slovakia

\section{Introduction}

Nursing includes a range of specialties and definitions that vary from country to country, but all the definitions support the importance of nurses for society. According to the International Council of Nurses, Nursing encompasses the autonomous and collaborative care of individuals of all ages, families, groups and communities, sick or well and in all settings. Nursing includes the promotion of health, prevention of illness, and caring for ill, disabled and dying people. Other key roles of nursing are advocacy, promotion of a safe environment, research, participation in shaping health policy and in patient and health systems management, and education (The International Council of Nurses, 2002). This definition describes how important this professional field is for all human beings. Nurses and midwives have key and increasingly important roles in our efforts to tackle the public health challenges of our time (WHO, 2000).

Nurses responsible for general care and midwives constitute the most significant group of employees in the health care institutions in Slovakia. Education of nurses and midwives has gone through significant change, largely due to Slovakia's accession to the European Union.

Looking at the history of the health care education in Slovakia, the year 1951 was the turning point in the development of institutionalized medical education in modern Slovak history. During this period, the education of nurses was purely organized through secondary health schools. From 1953, the secondary health schools were under the jurisdiction of the governmental health care department. For nurses, midwives and other categories of middle medical staff, a newly organized further education began in 1960 - established by the Institute for Further Education of Middle Medical Staff (Ministry of Health of the Slovak Republic, 2006). From 2003, the secondary health care schools have been under the jurisdiction of the Ministry of Education, but the Ministry of Health of the Slovak Republic guarantees the clinical and vocational part of the education. The Ministry of Health determines the network of study fields and can either include or exclude secondary health schools from the educational network in Slovakia.

\footnotetext{
* Corresponding author: Silvia Megyesiová, University of Economics in Bratislava, Faculty of Business Economy with seat in Košice, Tajovského 13, 04130 Košice, Slovak Republic; e-mail: silvia.megyesiova@euba.sk http://doi.org/10.32725/kont.2021.043

Submitted: 2021-04-28 • Accepted: 2021-10-04 • Prepublished online: 2021-10-13 
Most of the healthcare professions, such as physiotherapists, public health workers, radiological assistants, health rescue workers, dental hygienists, nutrition assistants, medical assistants, optometrists, opticians, dental technicians, orthopedic technicians, masseurs, and sanitarians, prepare for their professions in the secondary health schools.

A special position within the health care professional staff belongs to nurses and midwives who under the new legislation can gain their qualification by way of higher vocational education for general nurses in a relevant health school in the Slovak Republic, or they can obtain their qualification within a bachelor study program in nursing or midwifery (Bc.) - which represents the first level of the university education. After gaining the first level of university degree in a bachelor study program, nurses or midwives can continue their education by completing the second level of university education of nursing (Master's degree - Mgr.), or even the third level of doctoral study in nursing (PhD. study).

Significant changes in nursing education are not only typical for post-communist countries such as Slovakia; nursing education has gone through development in other countries too. Nurses need to be empowered with new skills that lead to a multidisciplinary approach in nursing education. As Lavizzo-Mourey (2012) stated, nurses will need advanced skills and expertise in care management, interdisciplinary teamwork, problem solving and more, to ensure that they maximize their contributions to health and health care. This makes higher levels of education imperative.

The profession of nurses has developed greatly over the past years, and the EC Directive for the Recognition of Professional Qualifications (Directive 2005/36/EC, 2005) outlines the practice of the learning experience and the minimum education requirements that professionals need to achieve in order to practice the profession within Europe.

Since the training of nurses in Slovakia differed considerably from EU expectations before its entry to the EU on 1st May 2004, the Slovak Republic had to gradually phase out the full secondary vocational training in nursing and leave only higher vocational and university education in nursing. Nowadays, the education of nurses is fully compatible with the expectations of the EU and the training corresponds to the Directive 2005/36/ EC of the European Parliament and the Council (2005).

According to the Directive 2005/36/EC (2005), the training of nurses responsible for general care shall comprise at least three years of study or 4,600 hours of (a) theoretical and (b) clinical training. The duration of the theoretical training representing at least one-third and the duration of the clinical training at least one half of the minimum duration of the training.

In 2010 , only about $13 \%$ of Slovak nurses and midwives were highly qualified and held a bachelor or a master diploma in nursing or midwifery (NCZI, 2011; 2012). In 2019 however, the proportion was as high as $34.6 \%$ (NCZI, 2021). To obtain higher education is not only a privilege for a person, but also often represents a possibility to increase the person's chances in the labor market.

A person with higher education finds it easier to secure a job in the labor market and has a generally higher income (Langhamrová et al., 2010).

The $\mathrm{PhD}$. program is not very popular among nurses. According to Nehls and Barber (2012) in the United States, it has been estimated that less than $1 \%$ of nurses have earned a doctoral degree in nursing or a related field. Thus the future of $\mathrm{PhD}$. education in nursing is at a crossroads.
Well-educated and prepared nurses are important in all societies. Quality patient care hinges on having a well-educated nursing workforce. Research has shown that lower mortality rates, fewer medication errors, and positive outcomes are all linked to nurses prepared at the bachelor and graduate degree levels, since education enhances both clinical competency and delivery of care (Aiken et al., 2003; 2014; Haegdorens et al., 2019; Kutney-Lee et al., 2013).

Demand for well-educated nurses will increase in the future. Accessible health care requires a well-trained and well-motivated nurse workforce of an adequate size which is able to deliver safe, high-quality medical services. However, concerns have been voiced in many OECD countries that a gap may be looming between the demand for and supply of nurses. Demand is likely to increase due to economic expansion, population growth, an ageing population, technological advances, and higher patient expectations (Simoens et al., 2005).

The main aim of this study was to analyze the changes of the nursing workforce in Slovakia. It was not only the absolute and relative changes of nurses and midwives that were subjected to analysis, an analysis of nursing workforce ageing was also performed. A comparability analysis of the number of nurses and midwives per 1,000 people in the EU countries was realized. The next objective was to detect the association between the number of the nursing workforce and the living standard in the EU countries.

\section{Materials and methods}

The fulfillment of the main aim of the study assumes the use of datasets on national (Slovak) and international levels. The number of nurses and midwives in Slovakia is regularly collected and published by the national authority (National Health Information Center of Slovakia). For international comparison, EU countries were selected because Slovakia has been an EU Member since 2004, and due to the availability of datasets on living standard for the EU population. The number of nurses and midwives per 1,000 people were collected from the World Bank database. The collection of datasets took place in January and February 2021.

The number of nurses and midwives in Slovakia and their age structure were collected from the Health Statistics Yearbook (published by the National Health Information Center of the Slovak Republic). This time series enabled us to follow the changes of the nursing workforce in Slovakia using chain indexes and/or fixed-base indexes. A chain index is an index number in which the value of any given period is related to the value of its immediately preceding period (Pacáková et al., 2009). This means that the previous period, in our case the previous year, is equal to 100 . A fixed-base index is an index number where the value of every period in a time series is related to the same value of fixed, unchanged base period (Pacáková et al., 2009). In our research the fixed base year was the year 2000, which enables us to study the change in the nursing workforce to the base year. The ageing of the nursing force was analyzed using the age structure and the average age of nurses and midwives in Slovakia. The proportion of nurses and midwives per 1,000 people in the EU countries was used to compare the situation of the nursing workforce as the ratio to population in these countries. These ratios can identify the shortage of nurses and midwives - especially in the countries with a low proportion of this variable. Correlation analysis was used to check the relationship between the living standard and 
number of nurses and midwives per 1,000 people. As a proxy for the living standard, the gross domestic product per capita was selected in the EU countries

\section{Results and discussion}

Although the number of midwives increased rapidly between 2000 and 2019 (Table 1), the decrease in the total number of nurses and midwives must be classified negatively. In 2000 the total number of nurses and midwives reached 40,380 , but in 2019 this number was only 33,041. This means that the trend was negative. The decrease in the analyzed time span reached $18.2 \%$, whilst the decline measured in persons was as high as 7,339 .

It is not only the trend of the total number of nurses that was negative. Looking at the age structure of nurses and midwives in 2000 and then following the changes until 2019, it becomes clear that the age distribution of nurses in Slovakia is changing dramatically. Unfortunately, the number of "young- er" nurses and midwives will not be sufficient to compensate for the number of nurses who are growing older and heading towards the age when most of them will enter well-deserved retirement. This is a typical problem in other developed countries too. Within nursing, the situation in many industrialized countries is that the nursing workforce is ageing (Sherman et al., 2013; Uthaman et al., 2016). Over the next 10 to 15 years, these countries will experience a large exodus of nurses from their workforce, with nurses retiring just at a time when the demand for nursing and health care is on the rise (one of the reasons for this is the growth in the older population). This trend, if left unaddressed, is set to deepen the current shortage of employed nurses, particularly in countries where there is a shortfall of new nurses entering the labor market or where the nurses decide to leave their profession (Graham and Duffield, 2010; Institute of Medicine, 2011; Kox et al., 2020; Marć et al., 2019). The ageing process of the nursing workforce can lead to a gap between supply and demand for nursing care and therefore a focus on promoting the nursing profession is recommended (Maresova et al., 2020).

Table 1. Nurses and midwives in Slovakia

\begin{tabular}{|c|c|c|c|c|c|}
\hline Year & Nurses & Midwives & Total & Previous year $=100$ & Based indexes $(2000=100)$ \\
\hline 2000 & 40077 & 303 & 40380 & - & 100.0 \\
\hline 2001 & 39073 & 355 & 39428 & 97.6 & 97.6 \\
\hline 2002 & 37265 & 1087 & 38352 & 97.3 & 95.0 \\
\hline 2003 & 35113 & 1456 & 36569 & 95.4 & 90.6 \\
\hline 2004 & 34007 & 1739 & 35746 & 97.7 & 88.5 \\
\hline 2005 & 32319 & 1719 & 34038 & 95.2 & 84.3 \\
\hline 2006 & 32568 & 1552 & 34120 & 100.2 & 84.5 \\
\hline 2007 & 34040 & 1659 & 35699 & 104.6 & 88.4 \\
\hline 2008 & 33778 & 1761 & 35539 & 99.6 & 88.0 \\
\hline 2009 & 32710 & 1769 & 34479 & 97.0 & 85.4 \\
\hline 2010 & 32745 & 1874 & 34619 & 100.4 & 85.7 \\
\hline 2011 & 32043 & 1837 & 33880 & 97.9 & 83.9 \\
\hline 2012 & 31478 & 1765 & 33243 & 98.1 & 82.3 \\
\hline 2013 & 31128 & 1775 & 32903 & 99.0 & 81.5 \\
\hline 2014 & 31166 & 1795 & 32961 & 100.2 & 81.6 \\
\hline 2015 & 30904 & 1760 & 32664 & 99.1 & 80.9 \\
\hline 2016 & 31183 & 1834 & 33017 & 101.1 & 81.8 \\
\hline 2017 & 30732 & 1736 & 32468 & 98.3 & 80.4 \\
\hline 2018 & 31061 & 1742 & 32803 & 99.4 & 81.2 \\
\hline 2019 & 31309 & 1732 & 33041 & 101.8 & 81.8 \\
\hline
\end{tabular}

In the year 2000, in the age group 20-24 years in Slovakia, a total of 5,688 nurses were employed. However, since then the situation has changed dramatically, and in the same age group only 969 nurses were active in 2019 (Fig. 1). The next age category of 25-29 also shows a negative trend of development. The number of nurses aged between 25 and 29 decreased from 5,381 in 2000 to only 1,471 in 2019. On the other hand, the structure of the nursing population indicates an increase in the total number of nurses aged 55 and over. So while in 2000 only 886 nurses were active in the 55-59 age group, this number increased to 4,169 in 2019. A large jump in nurses also occurred in the 60-64 age group, where the number of nurses increased from 218 to 2,669. In 2019, the number of nurses over 60 years of age was more than 13 times higher than in 2000. From this perspective, it is obvious that the demographic ageing process of the Slovak nurses is taking a dangerous direction. 


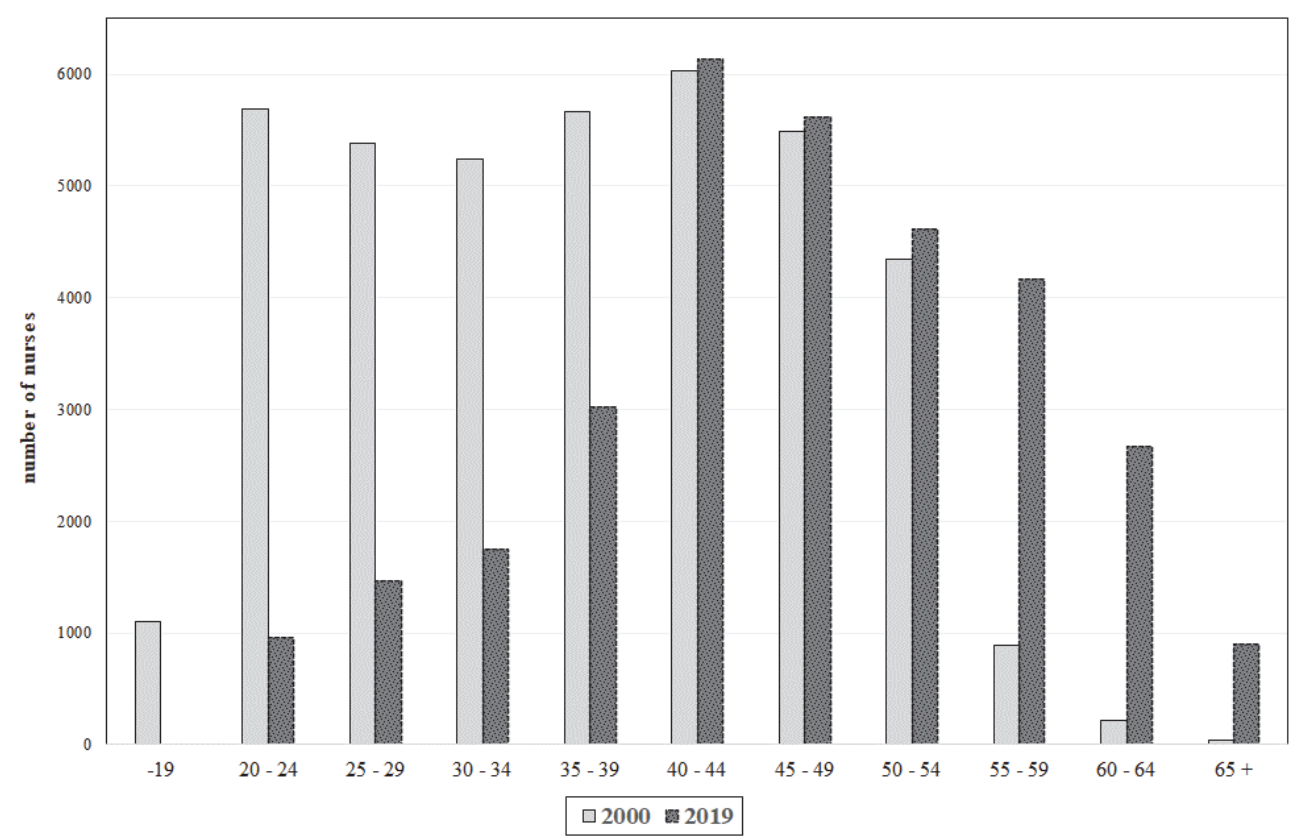

Source: Own presentation based on data extracted from the Health Statistics Yearbook of the Slovak Republic (NCZI, 2001-2012; 2014-2016; 2021).

Fig. 1. Age structure of nurses in Slovakia

A negative age structure is also evident in the comparison of changes in the age categories of midwives (Fig. 2). In 2000, the peak of the age structure of midwives is visible at the age of 45-49. The age distribution did not change positively over the course of twenty years, and in 2019 the dominance of midwives aged between $50-54$ and $55-59$ is conspicuous. Also radical was the increase of midwives aged over 60 years.

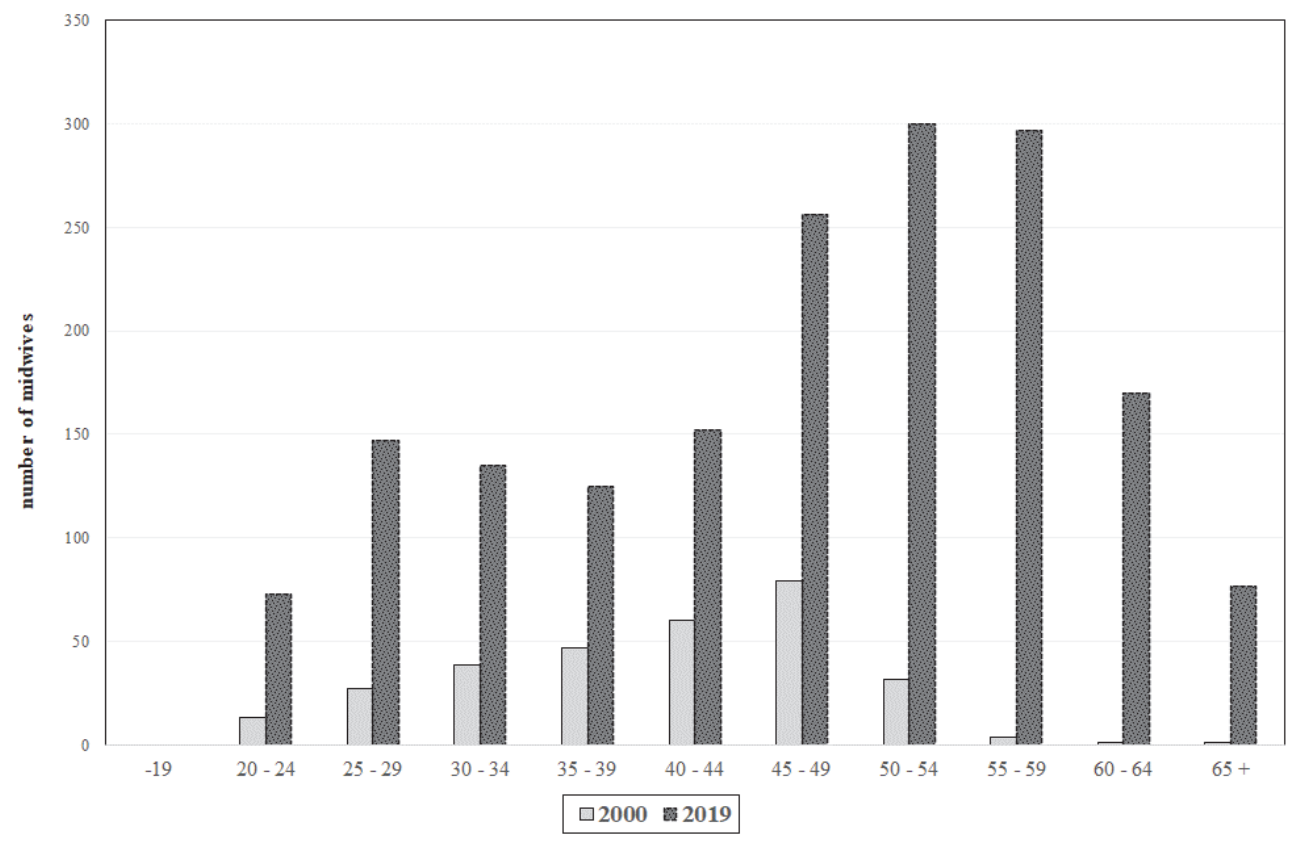

Source: Own presentation based on data extracted from the Health Statistics Yearbook of the Slovak Republic (NCZI, 2001-2012; 2014-2016; 2021).

Fig. 2. Age structure of midwives in Slovakia 
The changing age structure of nurses and midwives also caused a significant change in their mean age. The average age of nurses increased from 37.2 in 2019 to 46.9 in 2000. The average age of nurses rose by 9.7 years over the course of the analyzed time span. The ageing progress of midwives was similar (Fig. 3). In 2000 the average age of midwives was 40.9 and this increased by 6.4 by 2019 - reaching an average of 47.4 . The difference between the average age of nurses and midwives is not as high as it was at the beginning of the analyzed period. In 2000 the difference was as high as 3.7 years, but this declined to only $0.2-0.4$ in 2018 and 2019 (Fig. 3).

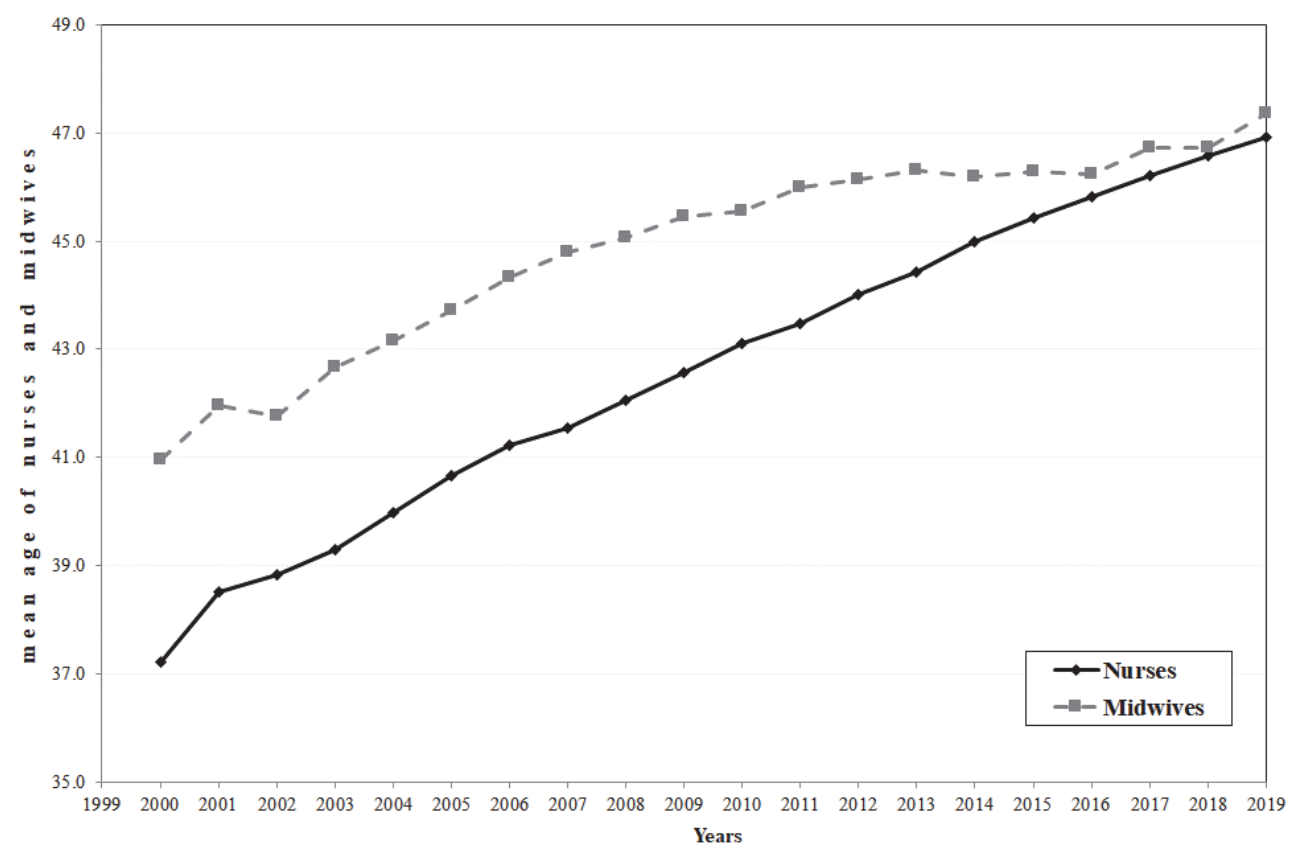

Source: Own presentation based on data extracted from the Health Statistics Yearbook of the Slovak Republic (NCZI, 2001-2012; 2014-2016; 2021).

Fig. 3. Average age of nurses and midwives in Slovakia

One reason for the age structure of nurses in Slovakia changing negatively may be the lower salaries of nurses. The lower salaries are inadequate to the importance of nurses' responsibilities. The profession of a nurse is not as attractive as in the past, especially for young people. In addition to the low compensation packages, the change in the system of health education has also caused a negative impact on the interest in studying to be a nurse. The surrounding countries such as Austria, the Czech Republic and some other EU countries offer nurses and midwives substantially higher salaries with enticing bonuses. A lot of well-educated nurses choose to work in another EU country, because EU legislation allows free movement of labor forces within EU Member States. According to a survey conducted by the Social Institute of the Slovak Academy of Sciences and a polling company in Slovakia, more than 16,000 home-carers from Slovakia are looking after elderly people in Austria. There was a significant increase in their number during the year 2009, which saw it jump from 6,000 up to the current state of 16,000 by the end of 2010 (according to estimations from the Labor Force Sample Survey provided by the Statistical Office of the Slovak Republic). The sharp increase between 2008 and 2010 was mainly caused by the change of the legislation in Austria. Before 2008, home-carers of elderly people in Austria worked mostly illegally, but then the situation changed and they gradually registered as care staff. Between 2007-2008 about 26\% of the Slovak home-carers in Austria had a health care education gained in Slovakia (Bahna, 2012).
Nurse density (i.e. the number of nurses per 1,000 people) will vary across countries. Variations in pay and conditions of service, productivity and nurse recruitment, can explain the supply variations across countries. At any one time, shortages and surpluses of nurses can occur if wages are set at a level in which supply does not match demand (Simoens et al., 2005). A nursing shortage is a negative sign for societies and can be caused by many factors. These factors include the ageing of the nursing workforce, the impact on nursing educators and enrollment rates, and the negative perception of the nursing profession. These contributing factors not only affect nurses in the profession, but most importantly, patient care.

In 2016, the number of nurses and midwives per 1,000 people ranged between 3.55 and 15.57 in the EU. 2016 was selected because the data for nurses and midwives were available for the EU countries in this year. The lowest values were typical for the less developed EU Member States, and the highest for the most developed EU Member States (Fig. 4). There were more than 11 nurses and midwives per 1,000 people in Sweden, Belgium, Luxembourg, Germany, Finland and Ireland, i.e., the "old" most developed EU countries. On the other hand, the ratio was lower than 5 in Greece, Latvia, and Bulgaria. The two new EU countries (Latvia, Bulgaria) belong to the less developed EU members, but surprisingly Greece reached the lowest number of nurses and midwives per capita among the EU states. The ratio in Slovakia was the eighth lowest. Slovakia and other post-communist countries reached lower number of nurses and midwives per 1,000 people. 


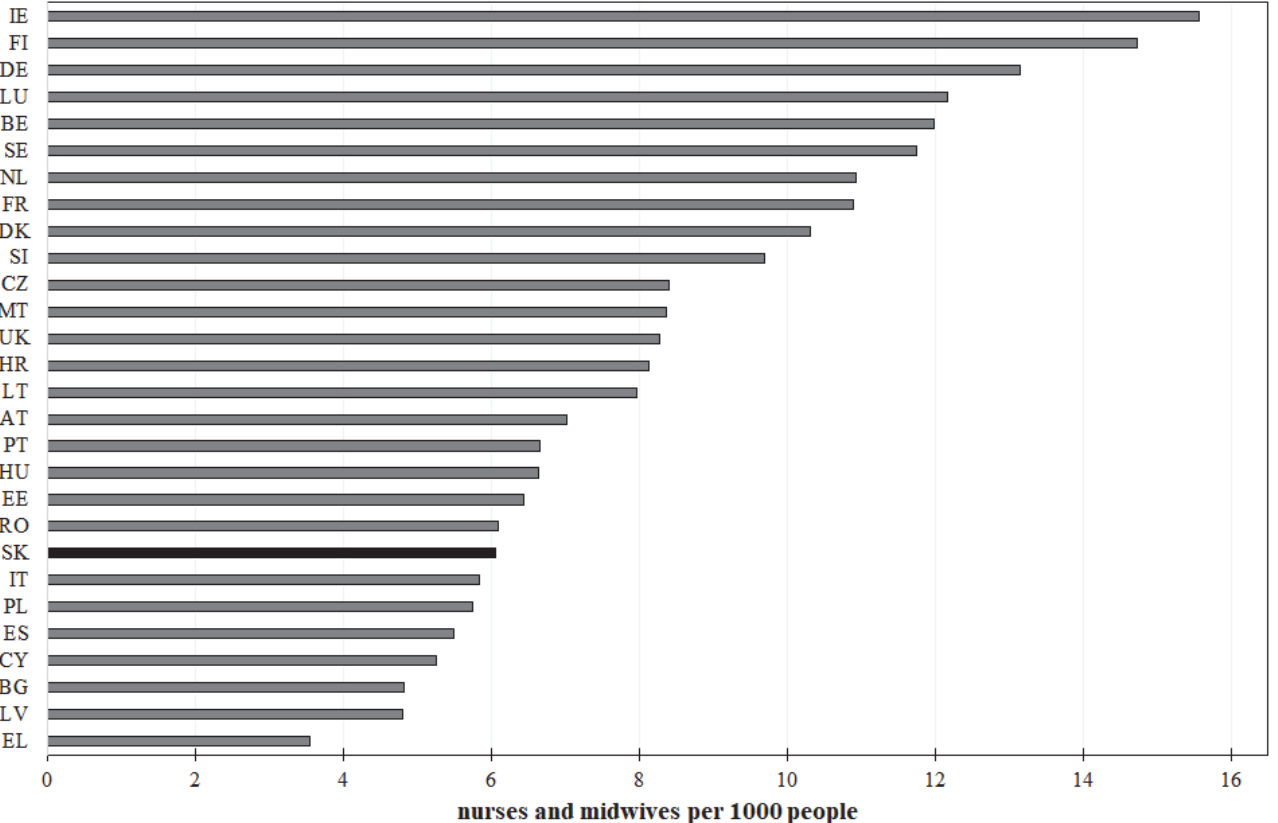

Source: Own presentation based on data extracted from World Bank Open data.

Country codes: AT - Austria, BE - Belgium, BG - Bulgaria, CY - Cyprus, CZ - Czechia, DE - Germany,

DK - Denmark, EE - Estonia, EL - Greece, ES - Spain, FI - Finland, FR - France, HR - Croatia, HU - Hungary,

IE - Ireland, IT - Italy, LT - Lithuania, LU - Luxembourg, LV - Latvia, MT - Malta, NL - Netherlands,

PL - Poland, PT - Portugal, RO - Romania, SE - Sweden, SI - Slovenia, SK - Slovakia, UK - United Kingdom.

Fig. 4. Nurses and midwives (per 1,000 people) in the EU countries, year 2016

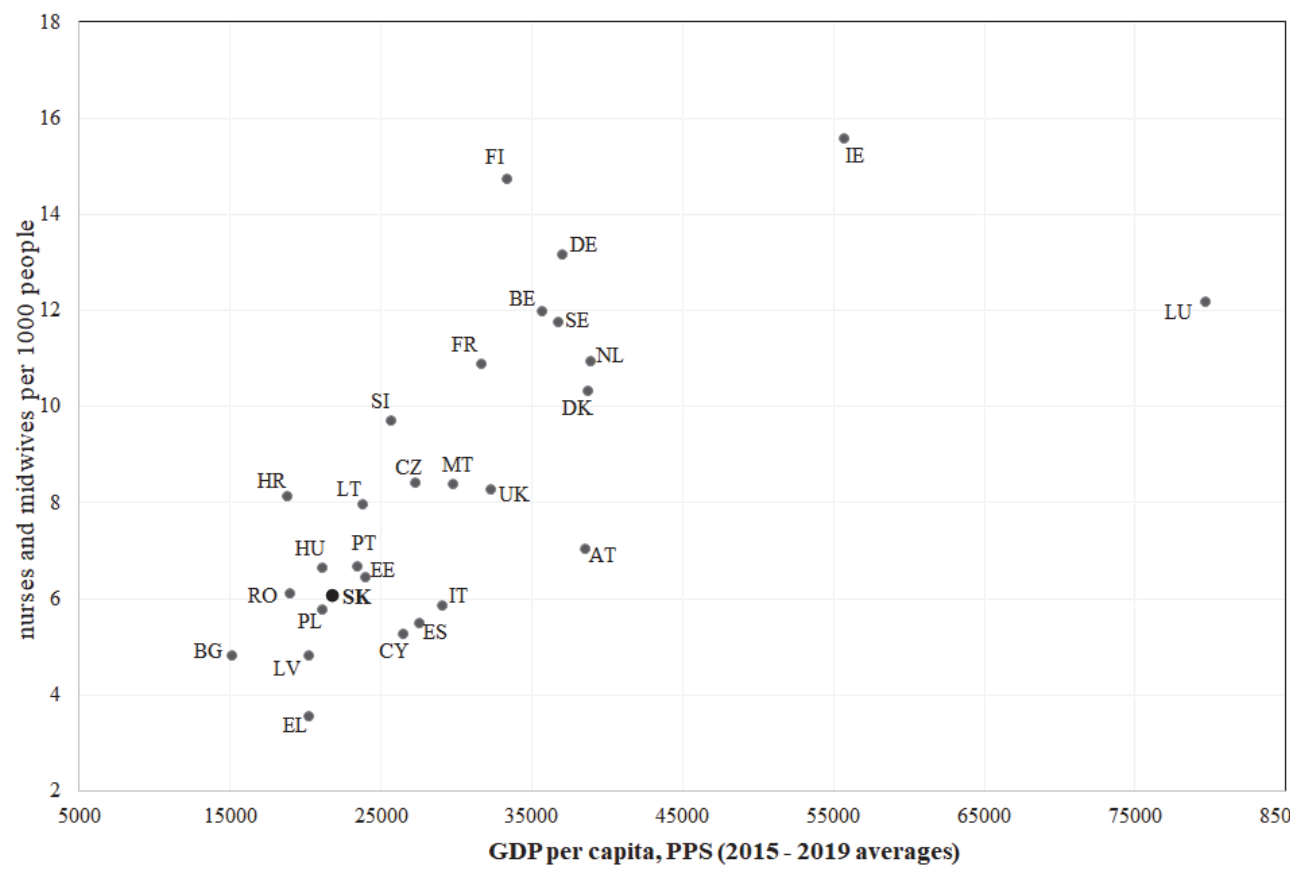

Source: Own presentation and calculation based on data extracted from World Bank Open Data (2016) and Eurostat database.

Fig. 5. Association between GDP per capita and number of nurses and midwives (per 1,000 people) 
Because the education of general nurses and midwifes in Slovakia is compatible with the education in other EU Member States, in principle their qualifications are recognized automatically in all EU Member States. The free movement of persons is one of the fundamental freedoms guaranteed by Community law. It is the most important right under Community law for individuals, and an essential element of European citizenship. Free movement of workers was guaranteed to EU nationals by the Treaty of Rome and was regulated by Regulation 1612/68 (Eurofound, 2011).

Whether skilled nurses will stay in Slovakia or whether they will try to find a job in another country will also depend on the political will of the Slovak government to solve the problem of the requirement to increase their salaries and create a better work environment for nurses. In the past, the situation of nurses led to them demonstrating their dissatisfaction in front of the Parliament in Bratislava, the capital city of Slovakia. The renumeration of nurses is a very important factor in relation to the satisfaction of nurses. It is one of the factors that influence the decision of well-educated nurses to leave their countries of origin and work abroad - often to countries with higher salaries (Gurková et al., 2013; Ivanová et al., 2013; Lee, 2019; Ribeiro et al., 2014).

The analysis of association between the Gross domestic product (GDP) per capita and the number of nurses and midwives shows a strong and positive correlation (Fig. 5). The association between the average GDP per capita in purchasing power standards (average for the years 2015-2019) and the number of nurses and midwives per 1,000 people (year 2016) is positive. The correlation coefficient was as high as 0.68 , and the coefficient was statistically significant ( $p$ value $<0.001$ ). When Luxembourg, which has an extremely high GDP per capita, was eliminated from the dataset, the correlation coefficient was much higher and reached 0.79 . The association unveils the fact that in countries with a higher living standard (measured by GDP per capita), the number of nurses and midwives is higher, whilst in the EU countries with lower GDP per capita the number of nurses and midwives (per 1,000 peo- ple) is lower. The correlation is high and positive and supports the expectations that in more developed countries with higher living standards, the nursing working staff's ratio to the population is higher. We hope that as the living standard in the "new" EU countries increases, so will the ratio of nurses and midwives to the entire population.

\section{Conclusions}

Recently, the number of nurses in Slovakia has decreased. The age structure of nurses is changing too - and unfortunately not in a positive way. The proportion of elderly nurses and midwives is increasing, and the coming generation of nurses will be insufficient to replace the numbers of nurses who will gradually retire.

In Europe, as well as in other developed countries, a nurse shortage is projected due to the "silver tsunami" of the baby boomer generation - which correlates with a growth in demand for nursing services. This nursing shortage influences the health and wellbeing of people all over the world - it is similar to a global public health crisis that affects many countries, including Slovakia. Whether skilled nurses will stay in Slovakia also depends on the political will of the Slovak government to solve the problem of renumeration of nurses, create a better work environment for the nursing workforce, and promote a better status for nurses and midwives in Slovak society.

\section{Ethical aspects and conflict of interests}

The author has no conflict of interests to declare.

\section{Acknowledgements}

I would like to express my gratitude to the management of the Faculty of Business Economy of the University of Economics in Bratislava with seat in Košice for supporting my research activities.

\section{Zdravotné sestry a pôrodné asistentky na Slovensku - dôležité trendy a starnutie sesterskej pracovnej sily}

\section{Súhrn}

Úvod: Zdravotné sestry a pôrodné asistentky zohrávajú v spoločnosti dôležitú úlohu a sú neodmyslitel'né pre každého jedinca. Sestry a pôrodné asistentky predstavujú na Slovensku najvýznamnejšiu skupinu zamestnancov zdravotníckych zariadení. Metodika: Počet sestier a pôrodných asistentiek na Slovensku sa analyzoval za obdobie rokov 2000 až 2019. Ret́azové indexy a/alebo bázické indexy boli použité na sledovanie zmien pracovnej sily v zdravotníctve. Starnutie sestier a pôrodných asistentiek bolo analyzované pomocou priemerného veku ako aj vekovou štruktúrou. Korelačná analýza bola použitá na stanovenie miery asociácie medzi životnou úrovňou a počtom sestier na 1000 obyvatel'ov v krajinách EÚ.

Výsledky: Celkový počet zdravotných sestier a pôrodných asistentiek na Slovensku sa znížil z 40380 v roku 2000 na 33041 v roku 2019. Tento pokles v počte sestier o 18,2 \% je negatívnym signálom pre slovenské zdravotníctvo. Starnutie sesterskej pracovnej sily je druhým negatívnym javom pre zdravotníctvo na Slovensku. Veková štruktúra zdravotných sestier a pôrodných asistentiek sa výrazne zmenila. Počet sestier nad 60 rokov bol v roku 2019 viac ako 13-krát vyšší v porovnaní s rokom 2000. Zmenená veková štruktúra mala za následok zvýšenie priemerného veku sestier. Priemerný vek zdravotných sestier bol v roku 2000 na úrovni 37,2 rokov a do roku 2019 sa zvýšil na 46,9. V prípade pôrodných asistentiek sa priemerný vek v tom istom období zvýšil z 40,9 na 47,4.

Záver: Pokles počtu sesterskej pracovnej sily v zdravotníctve spolu so starnutím zdravotných sestier a pôrodných asistentiek by mohol mat' za následok nedostatok sestier na Slovensku. Aby sa zastavil tento negatívny trend, slovenská vláda by mala aktívnejšie riešit' problém odmeňovania sestier, vytvorit' lepšie pracovné prostredie pre pracovnú silu v zdravotníctve a propagovat' dôležitost' a postavenie zdravotných sestier a pôrodných asistentiek na Slovensku. 


\section{References}

1. Aiken LH, Clarke SP, Cheung RB, Sloane DM, Silber JH (2003). Educational levels of hospital nurses and surgical patient mortality. JAMA 290(12): 1617-1623. DOI: 10.1001/ jama.290.12.1617.

2. Aiken LH, Sloane DM, Bruyneel L, Van den Heede K, Griffiths $P$, Busse R, et al. (2014). Nurse staffing and education and hospital mortality in nine European countries: A retrospective observational study. Lancet 383(9931): 1824-1830. DOI: 10.1016/s0140-6736(13)62631-8.

3. Bahna M (2012). Odchody za prácou v období ekonomickej krízy: Slovenské opatrovatel'ky v Rakúsku. Bratislava: Slovak Academy of Science. Institute for Sociology, pp. 1-3. [online] [cit. 2021-01-20]. Available at: http://www.sociologia.sav.sk/ cms/uploaded/1384_attach_podklady_pre_tk_31012012.pdf

4. Directive 2005/36/EC of the European Parliament and of the Council of 7 September 2005 on the recognition of professional qualifications (2005) [online] [cit. 2021-01-20] Available at: https://eur-lex.europa.eu/legal-content/EN/TXT/ $\mathrm{PDF} /$ ?uri=CELEX:32005L0036\&from=EN

5. Eurofound (2011). Free Movement of Workers. [online] [cit. 2021-01-20]. Available at: https://www.eurofound.europa.eu/ observatories/eurwork/industrial-relations-dictionary/freemovement-of-workers

6. Eurostat. Database. [online] [cit. 2021-02-03]. Available at: https://ec.europa.eu/eurostat/databrowser/view/nama_10_pc/ default/table?lang=en

7. Graham EM, Duffield C (2010). An Ageing Nursing Workforce. Aust Health Rev 34(1): 44-48. DOI: 10.1071/ah09684.

8. Gurková E, Soósová MS, Haroková, S, Žiaková K, Šerfelová R, Zamboriová M (2013). Job satisfaction and Leaving intentions of Slovak and Czech nurses. Int Nurs Rev 60(1): 112-121. DOI: 10.1111/j.1466-7657.2012.01030.x.

9. Haegdorens F, Van Bogaert P, De Meester K, Monsieurs KG (2019). The impact of nurse staffing levels and nurse's education on patient mortality in medical and surgical wards: An observational multicentre study. BMC Health Serv Res 19(1). DOI: $10.21203 / \mathrm{rs} .2 .13088 / \mathrm{v} 3$.

10. Institute of Medicine (2011). The future of nursing: Leading change, advancing health. Washington, DC: The National Academic Press, 700 p. DOI: 10.17226/12956.

11. Ivanová K, Vévoda, J, Nakládalová M, Marečková J (2013). Trends of job satisfaction in nurses. Kontakt 15(2): 115-127. DOI: 10.32725/kont.2013.015.

12. Kox JHAM, Groenewoud JH, Bakker EJM, BiermaZeinstra SMA, Runhaar J, Miedema HS, Roelofs /DDM (2020). Reasons why Dutch novice nurses leave nursing: A qualitative approach. Nurse Educ Pract 47:102848. DOI: 10.1016/j. nepr.2020.102848.

13. Kutney-Lee A, Sloane DM, Aiken LH (2013). An increase in the number of nurses with baccalaureate degrees is linked to lower rates of postsurgery mortality. Health Aff (Millwood) 32(3): 579-586. DOI: 10.1377/hlthaff.2012.0504.

14. Langhamrová J, Fiala T, Hulík V, Miskolczi M, Kačerová E (2010). Prognóza lidského kapitálu obyvatelstva České repuliky do roku 2050. Demografie 52(3): 181-196.

15. Lavizzo-Mourey R (2012). The Nurse Education Imperative. J Nurs Educ 51(5): 243-244. DOI: 10.3928/0148483420120419-01.

16. Lee E (2019). Why newly graduated nurses in South Korea leave their first job in a short time? A survival analysis. Hum Resour Health 17(1): 61. DOI: 10.1186/s12960-019-0397-x.

17. Marć M, Bartosiewicz A, Burzyńska J, Chmiel Z, Januszewicz P (2019). A nursing shortage - a prospect of global and local policies. Int Nurs Rev 66(1): 9-16. DOI: 10.1111/inr.12473.

18. Maresova P, Prochazka M, Barakovic S, Baraković Husić J, Kuca K (2020). A shortage in the number of nurses - A case study from a selected region in the $\mathrm{Czech}$ Republic and International Context. Healthcare, 8(2), 152. DOI: 10.3390/ healthcare8020152.
19. Ministry of Health of the Slovak Republic (2006). Education of Healthcare Professionals in the Slovak Republic. Bratislava, pp. 1-18.

20. NCZI (2001). Health Statistics Yearbook of the Slovak Republic 2000. Bratislava: Národné centrum zdravotníckych informácií, $193 \mathrm{p}$.

21. NCZI (2002). Health Statistics Yearbook of the Slovak Republic 2001. Bratislava: Národné centrum zdravotníckych informácií, $185 \mathrm{p}$.

22. NCZI (2003). Health Statistics Yearbook of the Slovak Republic 2002. Bratislava: Národné centrum zdravotníckych informácií, $183 \mathrm{p}$.

23. NCZI (2004). Health Statistics Yearbook of the Slovak Republic 2003. Bratislava: Národné centrum zdravotníckych informácií, $209 \mathrm{p}$.

24. NCZI (2005). Health Statistics Yearbook of the Slovak Republic 2004. Bratislava: Národné centrum zdravotníckych informácií, $197 \mathrm{p}$.

25. NCZI (2006). Health Statistics Yearbook of the Slovak Republic 2005. Bratislava: Národné centrum zdravotníckych informácií, $213 \mathrm{p}$.

26. NCZI (2007). Health Statistics Yearbook of the Slovak Republic 2006. Bratislava: Národné centrum zdravotníckych informácií, $201 \mathrm{p}$.

27. NCZI (2008). Health Statistics Yearbook of the Slovak Republic 2007. Bratislava: Národné centrum zdravotníckych informácií, $197 \mathrm{p}$.

28. NCZI (2009). Health Statistics Yearbook of the Slovak Republic 2008. Bratislava: Národné centrum zdravotníckych informácií, $207 \mathrm{p}$.

29. NCZI (2010). Health Statistics Yearbook of the Slovak Republic 2009. Bratislava: Národné centrum zdravotníckych informácií, $214 \mathrm{p}$.

30. NCZI (2011). Health Statistics Yearbook of the Slovak Republic 2010. Bratislava: Národné centrum zdravotníckych informácií, $230 \mathrm{p}$.

31. NCZI (2012). Health Statistics Yearbook of the Slovak Republic 2011. Bratislava: Národné centrum zdravotníckych informácií, $256 \mathrm{p}$.

32. NCZI (2014). Health Statistics Yearbook of the Slovak Republic 2012. Bratislava: Národné centrum zdravotníckych informácií, $255 \mathrm{p}$.

33. NCZI (2015). Health Statistics Yearbook of the Slovak Republic 2013. Bratislava: Národné centrum zdravotníckych informácií, $241 \mathrm{p}$.

34. NCZI (2016). Health Statistics Yearbook of the Slovak Republic 2014. Bratislava: Národné centrum zdravotníckych informácií, $242 \mathrm{p}$.

35. NCZI (2021). Zdravotnícka ročenka Slovenskej republiky 2019. Bratislava: Národné centrum zdravotníckych informácií, 242 p.

36. Nehls N, Barber G (2012). A prebaccalaureate PhD option: shaping the future of research-focused doctoral education. J Nurs Educ 51(1): 50-53. DOI: 10.3928/01484834-2011111606.

37. Pacáková V, Labudová V, Sipková L', Šoltés E, Vojtková M (2009). Štatistické metódy pre ekonómov. Bratislava: Iura Edition, $405 \mathrm{p}$.

38. Ribeiro JS, Conceição C, Pereira J, Leone C, Mendonça P, Temido, M, et al. (2014). Health professionals moving to... and from Portugal. Health Policy 114(2-3): 97-108. DOI: 10.1016/j. healthpol.2013.05.009.

39. Sherman RO, Chiang-Hanisko L, Koszalinski R (2013). The ageing nursing workforce: A global challenge. J Nurs Manag 21(7): 899-902. DOI: 10.1111/jonm.12188.

40. Simoens S, Villeneuve M, Hurst J (2005). Tackling Nurse Shortages in OECD Countries. OECD Health Working papers, pp. 1-58. [online] [cit. 2021-01-20]. Available at: https://www. oecd.org/health/health-systems/34571365.pdf

41. The International Council of Nurses (2002). Nursing Definitions. [online] [cit. 2021-01-15]. Available at: https:// www.icn.ch/nursing-policy/nursing-definitions 
42. Uthaman T, Chua TL, Ang SY (2016). Older nurses: A literature review on challenges, factors in early retirement and workforce retention. Proc Singapore Healthc 25(1): 50-55. DOI: $10.1177 / 2010105815610138$.

43. WHO (2000). Munich Declaration. Nurses and midwives: A Force for Health, 2000. WHO Regional Office for Europe. Copenhagen. Denmark, pp. 1-4. [online] [cit. 2021-01-20].
Available at: https://www.euro.who.int/_data/assets/pdf_ file/0007/53854/E93016.pdf

44. World Bank Open Data (2016). Nurses and midwives (per 1,000 people) - Slovak Republic [online] [cit. 2021-01-20]. Available at: https://data.worldbank.org/indicator/SH.MED.NUMW. P3?locations $=$ SK 